\title{
構造計算に基づく標的結合小型タンパク質の創製とがん治療への応用
}

\author{
門之園哲哉, ${ }^{*}$ 近 藤 科 江
}

\section{Semi-rational Design of Target-binding Small Proteins for Cancer Treatment}

\author{
Tetsuya Kadonosono* and Shinae Kizaka-Kondoh \\ School of Life Science and Technology, Tokyo Institute of Technology; \\ 4259 Nagatsuta-cho, Midori-ku, Yokohama 226-8501, Japan.
}

(Received July 29, 2019)

\begin{abstract}
Small proteins that have a high affinity for cancer cell surface markers can be promising cheap alternatives to antibodies (antibody mimetics). Various types of antibody mimetics have thus been extensively developed. We recently found that a target-binding peptide binds to its target molecule more strongly when it is structurally constrained. To apply this finding to the development of chemically synthesizable small antibody mimetics, we have established an efficient method of creating such proteins, named fluctuation-regulated affinity proteins (FLAPs). To identify desirable scaffolds, first, 13 human proteins (46-104 aa) were selected from the Protein Data Bank. Then, thirteen graft acceptor (GA) sites that efficiently immobilize the grafted peptide structure were identified from six small protein scaffolds using molecular dynamics simulation. To assess the designed antibody mimetics in vitro, human epidermal growth factor receptor 2 (HER2) -binding peptides were selected from the anti-HER2 antibody drugs trastuzumab and pertuzumab by calculating the binding energy, and these were then grafted into the GA sites of scaffolds to create 65 FLAP candidates. The FLAP candidates were expressed in bacteria as fusion proteins with Renilla luciferase (Rluc), and their relative binding affinity to HER 2 was easily determined by measuring the Rluc bioluminescence intensity without protein purification. Finally, four out of the 65 showed specific binding to HER2 with a dissociation constant $\left(K_{\mathrm{D}}\right)$ of $24-65 \mathrm{nM}$, and these were used for the detection of HER2-expressing cancer cells. Our design strategy will promote the development of antibody mimetics for the effective treatment of cancers and other diseases.
\end{abstract}

Key words_ antibody mimetics; constrained peptide; small protein scaffold

\section{1.はじめに}

近年，抗体の強い結合力を利用して標的分子を認 識する抗体医薬の開発が盛んに進められ，がんを始 めとする様々な疾患の治療に用いられている. 抗体 医薬は生体内で安定に長期間存在でき，免疫システ ムとの共役による細胞障害活性, シグナル中和活 性，アゴニスト活性など多様な薬効を持たせること ができる。また，抗体を抗原発現細胞への薬剂輸送 キャリアとして利用した抗体薬物複合体 (antibody-drug conjugate; ADC) や画像診断プロー ブが開発され，光免疫療法への応用も検討されてい る.このように抗体医薬は非常に有用な薬剤である

東京工業大学生命理工学院（下226-8501 横浜市緑区長 津田町 4259)

*e-mail: tetsuyak@ bio.titech.ac.jp

本総説は, 日本薬学会第 139 年会シンポジウム S08 で

発表した内容を中心に記述したものである.
一方で，分子量 $150 \mathrm{kDa}$ の大きなタンパク質であ るため組織浸透性が低く適用疾患が限られてしまう ことや，細胞膜を透過できないため標的にできる分 子の種類が少ないことなど, いくつかの大きな課題 が残っている．これらの課題を克服するために，小 さな分子量でありながら抗体の機能を代替できる小 型タンパク質医薬の開発が注目されている. ${ }^{1-5)}$

標的分子に特異的に強く結合するぺプチドや小型 タンパク質（分子量 3-12 kDa）は，抗体医薬と同 様に様々な疾患の分子標的治療薬としての利用が期 待できる.このような標的結合小型タンパク質は抗 体よりも組織浸透効率や体外排出効率が高く, 細胞 膜に発現する分子に限らず細胞内に局在する分子も 標的として利用できるため, 従来の抗体医薬を凌ぐ 治療薬を開発することも可能である。 そのため, 新 たな創薬モダリティとして臨床応用するために, 標 的結合小型タンパク質のデザイン技術の高度化と汎 
用化が進められている.

従来，標的結合小型タンパク質を開発するために は分子進化工学的手法が多用される. ${ }^{6-8)}$ まず, 特 定の小型タンパク質を足場骨格として選択し，次に それらの分子表面に存在するアミノ酸残基を他の 19 種類のアミノ酸へとランダム置換した分子ライ ブラリーを作成し，その中から各種迅速スクリーニ ング法によって標的に強く結合する分子を取得す る。この場合，網羅性に優れたスクリーニングが実 現できるものの，ランダム化する残基が 1 つ増える ごとにライブラリーサイズが 20 倍になるため，各 スクリーニング方法のライブラリーサイズの制限に 依存して, 必然的にランダム化できる残基の数は限 られてしまう。また，結合領域を選択できないため 期待する場所に結合するとは限らず，標的結合分子 を取得できたとしても薬効を示さないことがある.

一方，スーパーコンピュータの高性能化と計算科学 的手法の進歩により，構造計算で標的との結合構造 をデザインし，合理的に標的結合分子を取得するこ とが可能になりつつある。しかし，分子間の結合構 造を正確に予測できる一般的な方法はまだ確立され ておらず，計算技術の高精度化による汎用性の拡大 が課題となっている.

このような状況の中，筆者らを含むいくつかの研 究グループは, 計算科学的手法と迅速スクリーニン グ法を組み合わせた半合理的デザイン技術の開発を

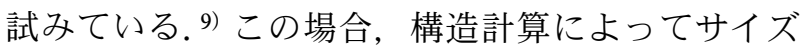
の小さなライブラリーを作成し，迅速スクリーニン グによってすべての候補分子を評価することが特徵 である。これにより，現段階での構造計算技術の不 完全性をカバーすることが可能になる。本稿では, 筆者らが開発してきた半合理的デザイン技術の例と して，抗体構造中の抗原結合ペプチドを利用した標 的結合小型タンパク質のデザインについて概説する.

\section{2. 標的結合小型タンパク質のデザインコンセプ} 卜

抗体分子内で直接抗原と結合する領域は相補性決 定領域 (complementarity determining region; CDR) と呼ばれ，合計 6 本の CDR ループが存在してい る. ${ }^{10)}$ それぞれの CDR ループの 5-10程度のアミノ 酸配列（CDR ペプチド）は抗体によって異なり, この違いによって様々な抗原結合表面を形成するこ とで，抗原特異的に結合することができる．このこ
とから，CDR ペプチドを利用した抗原結合分子の 開発が試みられてきたが，ほとんどの場合 CDR 由 来直鎖ペプチドは抗原に結合しないことが知られて おり，これまでに医薬品として認可された例はな い.この原因の 1 つとして, 筆者らはペプチドの構 造ゆらぎに注目した。つまり，抗体分子内では一定 の構造に保たれている CDR ペプチドであっても, 直鎖ペプチド化すると溶液中で様々な構造をとるこ とが可能になる，そのため，直鎖 CDR ペプチドが 抗原と結合するには構造を固定化する必要があり, 大きなエントロピー損失が生じる，その結果，結合 エネルギーが弱くなると考えた。この仮説を検証す るために, 複数の抗体分子構造を分子動力学 (molecular dynamics; MD) シミュレーションに よって解析したところ, 同じ配列の CDR ペプチド であっても抗体分子内にある場合と直鎖の場合では 構造ゆらぎは大きく異なり，抗体骨格の働きによつ て CDR ペプチドの構造ゆらぎが抑制されているこ とが示唆された。 さらに，抗体の成熟過程において CDR ペプチドのアミノ酸配列だけでなく，構造ゆ らぎも最適化されていることを支持する報告も増え てきている. ${ }^{11-14)}$ これらの解析結果や先行研究を受 けて，抗体骨格に替わる小型タンパク質に CDR ペ プチドを組み込んで構造ゆらぎを抑制することによ り，結合力の強い抗原結合分子を創出するというデ ザインコンセプトが立てられた 。

\section{3. 標的結合小型タンパク質 FLAP の創出}

タンパク質構造データベース Protein Data Bank には，現在 15 万件以上が登録されている。この中 から，CDR ペプチドを組み込むのに適した足場と なる小型タンパク質を探索するために，イン・シリ コ・スクリーニング法を開発した。この方法は MD シミュレーションをベースにしており，どのような アミノ酸配列を持つペプチドと置換してもその構造 ゆらぎを抑制できるループ領域（graft acceptor サ イト；GA サイト）を持った足場タンパク質を同定 することができる。この探索方法を用いて，13 種 類の小型のヒト由来タンパク質 (分子量 5-11 kDa) の構造を評価したところ，6 種類の小型タンパク質 内に 13 力所の GA サイトを同定できた。 そこで, モデルとして human epidermal growth factor receptor 2（HER2）結合抗体医薬 trastuzumab 及び pertuzumab から 5 種類の HER2 結合 CDR ペプチド配 


\section{BL-ELISA}

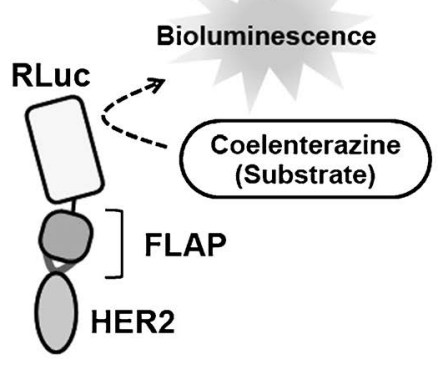

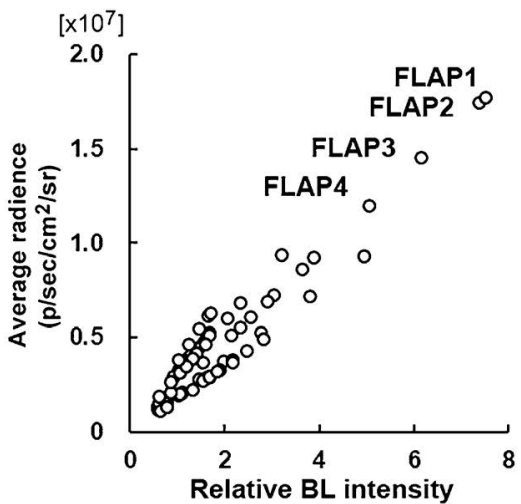

Fig. 1. Rapid Evaluation of FLAP Candidates

(Left) Schematic diagram of the RLuc-fused FLAP structure and the principal for affinity determination by BL-ELISA. The affinity of FLAP candidates to HER2 was quantified by the bioluminescence (BL) signal intensity obtained by the reaction between RLuc and coelenterazine. (Right) HER2-Fc affinity of the 65 FLAP candidates. HER2 affinity of FLAP candidates were evaluated by BL-ELISA. The average radiance of each well and their relative intensity toward the value of scaffold proteins are shown.

列を抽出し, 13 カ所のループ領域と置換して合計 65 種類の候補分子をデザインした。これらの候補 分子を MD シミュレーションで解析すると，予想 通り，組み込まれた CDR ペプチドの構造ゆらぎは すべて抑制されていることが確認できた.

デザインした 65 種類の候補分子の結合力を簡便 に評価するために，ウミシイタケ由来ルシフェラー ゼ RLucを利用する生物発光 ELISA 法 (bioluminescence enzyme-linked immunosorbent assay；BL-ELISA）を新たに開発した。本法において は，評価したい候補分子タンパク質とRLucの融合 タンパク質を大腸菌内で発現させ，菌体破砕上清の 生物発光活性をイメージングで測定することで，含 まれる候補分子タンパク質の量を揃えたサンプルを 調製した。続いて，一般的な ELISA と同様に 96 well プレート内で融合タンパク質を抗原と反応さ せ，抗原結合量を生物発光イメージングにより測定 する (Fig. 1)。 BL-ELISA システムにより 65 種類 の候補分子の HER2 への結合力は簡便かつ迅速に 比較でき， 4 種類の小型タンパク質が強く HER2 に 結合できることが分かった．筆者らは，このように 構造ゆらぎが抑制されたペプチドを有する標的結合 タンパク質を, fluctuation-regulated affinity protein (FLAP) と名付けた。これらの HER2 結合 FLAP は比較的強く HER2 に結合し $\left(K_{\mathrm{D}}=24-65 \mathrm{nM}\right)$, 非特異吸着はほとんどみられなかった。また, FLAP と FLAP 認識蛍光抗体を用いて HER2 過剩 発現がん細胞株を容易に検出できた（Fig. 2). FLAP は分子量 $10 \mathrm{kDa}$ と小さいことから, HER2

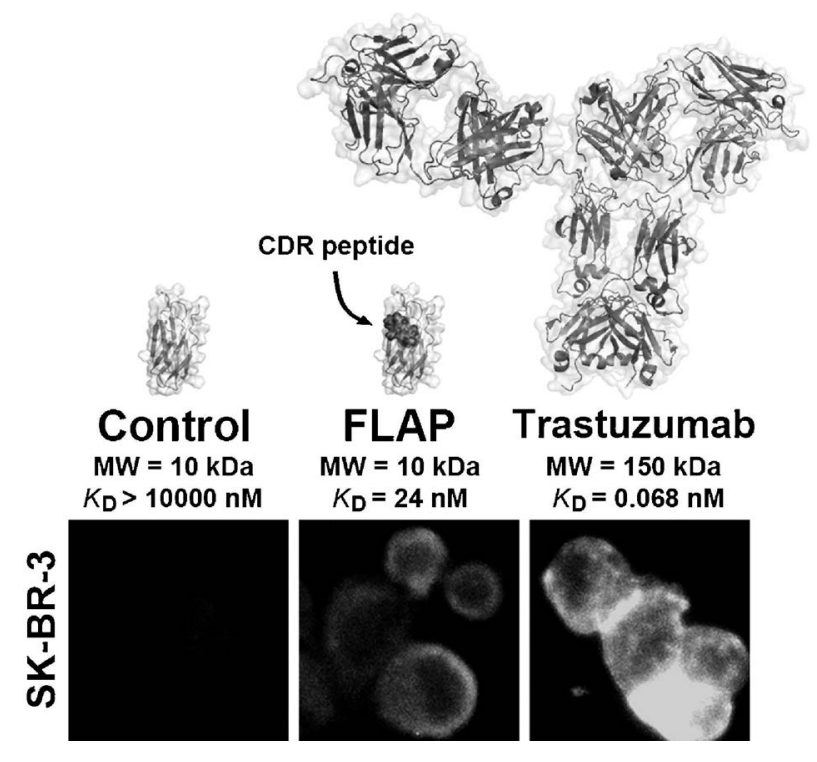

Fig. 2. Characterization of Anti-HER2 FLAPs

Immunostaining of HER2-expressing SK-BR-3 cells with His-tagged FLAP1 or trastuzumab. The Alexa Fluor 488-conjugated mouse anti-His tag secondary antibody or Alexa Fluor 488-conjugated mouse anti-human IgG Fc secondary antibody were used to fluorescently label the His-tagged FLAP1 or trastuzumab, respectively.

結合抗体医薬の機能を代替可能な小型タンパク質医 薬候補として期待される.

\section{FLAP の高度化と医療応用}

本稿では，標的結合小型タンパク質デザインの例 として，HER2 抗体の CDR ペプチドを組み込んだ HER2 結合 FLAP デザインを紹介した。このデザ イン技術は抗原との複合体構造が明らかになってい るすべての抗体に対して応用できるため，様々な抗 体医薬の代替小型タンパク質の創出につながると期 待される. 現在は，標的結合ペプチドの構造ゆらぎ 
制御をキーワードとして，様々なコンセプトに基づ く標的結合小型タンパク質デザイン技術の考案と検 証を進めており，この過程で得られる小型タンパク 質を利用したドラッグデリバリーシステム開発にも 取り組んでいる. ${ }^{15)}$ 今後，さらにデザイン技術の高 度化と汎用化を達成することにより，画期的な医薬 品の開発を実現したい.

謝辞 本研究は, 科研費挑戦的萌芽研究, 武田 科学振興財団医学系研究奨励の助成を受けて実施し たものであり，ここに感謝申し上げます。

\section{利益相反＼cjkstart開示すべき利益相反はない，}

\section{REFERENCES}

1) Löfblom J., Frejd F. Y., Ståhl S., Curr. Opin. Biotechnol., 22, 843-848 (2011).

2) Richards D. A., Drug Discov. Today, 30, 3546 (2018).

3) Škrlec K., Štrukelj B., Berlec A., Trends Biotechnol., 33, 408-418 (2015).

4) Vazquez-Lombardi R., Phan T. G., Zimmermann C., Lowe D., Jermutus L., Christ D., Drug Discov. Today, 20, 1271-1283 (2015).

5) Weidle U. H., Auer J., Brinkmann U., Georges G., Tiefenthaler G., Cancer Genomics Proteomics, 10, 155-168 (2013).

6) Friedman M., Nordberg E., Höidén-Guthenberg I., Brismar H., Adams G. P., Nilsson F. Y., Carlsson J., Ståhl S., Protein Eng. Des. Sel., 20, 189-199 (2007).

7) Ramamurthy V., Krystek S. R. Jr., Bush A.,
Wei A., Emanuel S. L., Das Gupta R., Janjua A., Cheng L., Murdock M., Abramczyk B., Cohen D., Lin Z., Morin P., Davis J. H., Dabritz M., McLaughlin D. C., Russo K. A., Chao G., Wright M. C., Jenny V. A., Engle L. J., Furfine E., Sheriff S., Structure, 20, 259269 (2012).

8) Zahnd C., Wyler E., Schwenk J. M., Steiner D., Lawrence M. C., McKern N. M., Pecorari F., Ward C. W., Joos T. O., Plückthun A., $J$. Mol. Biol., 369, 1015-1028 (2007).

9) Chevalier A., Silva D. A., Rocklin G. J., Hicks D. R., Vergara R., Murapa P., Bernard S. M., Zhang L., Lam K. H., Yao G., Bahl C. D., Miyashita S. I., Goreshnik I., Fuller J. T., Koday M. T., Jenkins C. M., Colvin T., Carter L., Bohn A., Bryan C. M., FernándezVelasco D. A., Stewart L., Dong M., Huang X., Jin R., Wilson I. A., Fuller D. H., Baker D., Nature, 550, 74-79 (2017).

10) Sela-Culang I., Kunik V., Ofran Y., Front. Immunol., 4, 302 (2013).

11) Babor M., Kortemme T., Proteins, 75, 846858 (2009).

12) Manivel V., Sahoo N. C., Salunke D. M., Rao K. V., Immunity, 13, 611-620 (2000) .

13) Thorpe I. F., Brooks C. L. 3rd, Proc. Natl. Acad. Sci. USA, 104, 8821-8826 (2007).

14) Wong S. E., Sellers B. D., Jacobson M. P., Proteins, 79, 821-829 (2011).

15) Kadonosono T., Yamano A., Goto T., Tsubaki T., Niibori M., Kuchimaru T., Kizaka-Kondoh S., J. Control. Release, 201, 14-21 (2015) . 